\title{
New Essays
}

IN

\section{Ethics and Public Policy}

\author{
Edited by \\ Kai Nielsen and Steven C. Patten
}

OCANADIAN ASSOCIATION FOR PUBLISHING IN PHILOSOPHY GUELPH, ONTARIO

1982

ISSN 0045-5091

ISBN 0-919491-08-1 


\section{EDITORS' PREFACE}

The select bibliographies at the end of each section have been put together by the authors. They represent a limited set of readings that the aùthors judge to be of particular value on the topics of the essays.

The editors of this volume gratefully acknowledge the advice and assistance of Lila Spencer, Barry Allen and Lana Cooke.

K.N.

S.C.P. 


\section{Table of Contents}

Mechanics on Duty: The Limitations of a Technical Definition of Moral Expertise for Work in Applied Ethics ........... 1 Arthur L. Caplan

The Moral Equivalence of Action and Omission . . . . . . . . . . . 19 Judith Lichtenberg

Acts, Omissions, and Common Sense Morality . . . . . . . . . 37 Laurence Thomas

Autonomy and Paternalism . . . . . . . . . . . . . . . . 47 Robert Young

Paternalism and Justification ................... 67 James Woodward

The Ethics of Consent . . . . . . . . . . . . . . . . . . . . 91 John Kleinig

Rape and Mens Rea . . . . . . . . . . . . . . . . . . . . . . 119 M.T. Thornton

Moral Contracts and the Morality of Abortion. . . . . . . . . . . . 147 A.T. Nuyen

Justification or Excuse: Saving Soldiers at the

Expense of Civilians

Paul Woodruff

The Right to Know in the Workplace

Ruth R. Faden and Tom L. Beauchamp

Commerce and Selfishness .................... 211 Richard J. Arneson

Notes on Contributors . . . . . . . . . . . . . . . . . 233 